\title{
EFFECT OF ORGANIC AND MINERAL FERTILIZATION ON PRODUCTIVITY OF SOME WHEAT CULTIVARS
}

Salama, A. M. A.*; E. M.Said";E.E.E.Khafagy ${ }^{\star *}$ and A.K.E. Seadh ${ }^{* *}$ Agronomy Department, Faculty of Agriculture, Mansoura University, Egypt .

" Soil Fertility and Plant Nutrition Research Department, Soils, Water and Environment Research Institute, Agricultural Research Center, Giza, Egypt.

ABSTRACT

Two field experiments were conducted at the Experimental Research Station in El-Serw, Agricultural Research Center during 2010/2011 and 2011/2012 seasons to study the effect of nitrogen and compost combination treatments and potassium fertilizer levels on growth, yield and its components as well as grain quality of some wheat cultivars. The experiments were carried out in a strip-split plot design with three replicates. The vertical plots were assigned to wheat cultivars (Sakha 93, Gemmiza 9 and Gemmiza 10). The Horizontal plots were devoted to nitrogen and compost combination treatments as follows: 1) $100 \%$ mineral nitrogen (90 kg/fed). 2) $75 \%$ mineral nitrogen $(67.5 \mathrm{~kg} / \mathrm{fed})+25 \%$ organic nitrogen "compost" $(22.5 \mathrm{~kg} / \mathrm{fed}) .3) 50$ $\%$ mineral nitrogen $(45.0 \mathrm{~kg} / \mathrm{fed})+50 \%$ organic nitrogen "compost" $(45.0 \mathrm{~kg} / \mathrm{fed}) .4)$ $25 \%$ mineral nitrogen $(22.5 \mathrm{~kg} / \mathrm{fed})+75 \%$ organic nitrogen "compost" $(67.5 \mathrm{~kg} / \mathrm{fed})$ 5) $100 \%$ organic nitrogen "compost" $(90 \mathrm{~kg} / \mathrm{fed})$. While, the sub - plots were allocated to potassium fertilizer levels ( 0 and $48 \mathrm{~kg} \mathrm{~K}{ }_{2} \mathrm{O} / \mathrm{fed}$ ).

Results showed that Gemmiza 10 cultivar surpassed other studied cultivars in number of days to heading, flag leaf area, plant height, number of spikes $/ \mathrm{m}^{2}$, number of spikelets/spike, number of grains/spike, grains weight/spike, grain and straw yields/fed, potassium content in grains in both seasons. However, Gemmiza 9 cultivar produced the longest spikes and the highest values of protein percentage in grains in both seasons. Whereas, Sakha 93 cultivar recorded the highest values of $1000-$ grain weight at the same time the lowest values of other studied characters in both seasons.

Application of $100 \%$ mineral nitrogen fertilizer alone produced the highest values of all studied characters. Application of $75 \%$ mineral nitrogen $(67.5 \mathrm{~kg} / \mathrm{fed})+$ $25 \%$ organic nitrogen "compost" $(22.5 \mathrm{~kg} / \mathrm{fed})$ came in the second rank after application of $100 \%$ mineral nitrogen alone without significant differences between them in some studied characters in both seasons.

All studied characters of wheat plants gradually increased as a result of increasing potassium fertilizer levels from 0 to $48 \mathrm{~kg} \mathrm{~K} \mathrm{~K}_{2} \mathrm{O} / \mathrm{fed}$ in both seasons. Generally, maximum means of all studied characters were produced from fertilizing wheat plants with $48 \mathrm{~kg} \mathrm{K2O} / \mathrm{fed}$ in both seasons.

It could be recommended that fertilizing Gemmiza 10 cultivar plants with mineral nitrogen $(67.5 \mathrm{~kg} \mathrm{~N} / \mathrm{fed})+\operatorname{compost}(22.5 \mathrm{~kg} \mathrm{~N} / \mathrm{fed})+48 \mathrm{~kg} \mathrm{~K} \mathrm{~K}_{2} \mathrm{O} / \mathrm{fed}$ to enhance wheat productivity and also to reduce sources of environmental pollution and maintain human health.

Keywords: Wheat, Organic fertilizer, Compost, nitrogen fertilizer, potassium fertilizer, cultivars, varieties. 
Salama, A. M. A. et al.

\section{INTRODUCTION}

Wheat (Triticum aestivum L.) is one of the most important nutritional cereal crops in Egypt and all over the world. Wheat is the stable food crop of the urban areas; moreover it is used widely in blending with maize flour in rural areas to make bread, macaroni, biscuit and sweets. It is also worth mentioning that wheat straw is a source of fodder for animals. Wheat production is not sufficient for local consumption in Egypt. This calls for greater attention of all the concerned to increase the production to meet the continuous demand and reduce the gap between the production and consumption of wheat. Therefore, great efforts have been made to achieve suitable agronomic practices for obtaining maximum productivity of different wheat varieties with optimum quality properties.

Chosen the high yielding ability cultivars undoubtedly is very important to raise wheat productivity per unit area. For this reason, this study is aiming to evaluate the new promising cultivars with the old traditional ones for scooping light on the best cultivars that can be used under the environmental conditions of study region. El-Metwally et al. (2012) found that the largest flag leaf area resulted from Sakha 93 and Gemmeiza 9. Sakha 94 cultivar significantly surpassed all cultivars in plant height, while Gemmeiza 10 gave the highest number of spikes $/ \mathrm{m}^{2}$, while 1000-grain weight of Sakha 93 was the largest. The highest grain yield was achieved with Sakha 94 and Gemmeiza 9. Harb et al. (2012) revealed that Gemmeiza 9 cultivar exceeded Sakha 93 cultivar significantly in number of spikes $/ \mathrm{m}^{2}$, weight of grains/spike, number of grains/spike, 1000-grain weight and grain yield/fed. Atia and Ragab (2013) found that wheat cultivars significantly differed in grain and straw yields as well as protein and potassium contents in grains. Gemmeiza 9 cultivar had the highest values of grain and straw yields as well as protein and potassium contents in grains. Seleem and Abd El -Dayem (2013) showed that the highest significant value of grain yield was obtained by Gemmeiza 9 followed by Misr 1 then Sakha 94 and Giza 168. Vice versa, the lowest ones resulted from Sakha 93 cultivar.

The continued use of chemical fertilizers causes health and environmental hazards such as ground and surface water pollution by nitrate leaching. So, reducing the amount of nitrogen fertilizers applied to the field without a nitrogen deficiency will be the main challenge in field management. One of the possible options to reduce the use of chemical fertilizer could be recycling of organic wastes. Compost as the organic waste can be a valuable and inexpensive fertilizer and source of plant nutrients. Positive effects of compost on soil structure, aggregate stability and water-holding capacity were reported (Odlare et al., 2008). Moreover, the combination of compost with nitrogen fertilizer further enhanced the biomass and grain yield of wheat crop in this regard, Mahmoud et al. (2006) found that grain and straw yields of wheat and $\mathrm{N}, \mathrm{P}$ and $\mathrm{K}$ uptake in grains and straw as well as crude protein content were increased by application of $75 \%$ of $\mathrm{N}$ as ammonium sulfate with $25 \%$ composting rice straw. Abedi et al. (2010) evaluated the effects of different levels of inorganic $(0,80,160$ and $240 \mathrm{~kg} \mathrm{~N} / \mathrm{ha})$ and organic (0, 30 
and $60 \mathrm{Mg}$ municipal waste compost ha-1) fertilizers on wheat grain yield and protein content. They reported that the highest wheat grain yield was achieved when the plants were fertilized with $160 \mathrm{~kg} \mathrm{~N} / \mathrm{ha}$ and $30 \mathrm{Mg}$ compost/ha. The highest amount of seed protein was obtained with $60 \mathrm{Mg}$ compost/ha at all levels of nitrogen. Antoun, Linda et al. (2010) found that the interaction between compost and mineral nitrogen level had significant effects on 1000-grain weight, grain yield/fed and N, P and $\mathrm{K} \%$ in grains. El-Hamdi et al. (2012) reported that the combination of compost and nitrogen fertilizer improved yields, yield components and $\mathrm{N}$-uptake. The best treatment was 50 $\mathrm{kg} \mathrm{N} / \mathrm{fed}$ with adding 10 tons compost/fed.

Potassium is important for the function of the stomata, pore-like openings of the plant leaves, through which transpiration of water and uptake of gaseous carbon dioxide occurs. Adequate potassium nutrition of the plant is necessary to ensure the integrity of the water economy within the plant. Thus, many experiments have shown that potassium fertilizer has apparently increased wheat grain yield. In this concern, Slaton et al. (2007) concluded that the potential benefits of providing sufficient potassium for wheat often include promoting early plant maturity, resistance to diseases and other pests, stalk strength, tillering, vigorous growth, and improved yield. Tahir et al. (2008) revealed that heading date, flag leaf area, plant height, number of spikes $/ \mathrm{m}^{2}$, spike length, grains weight/spike, 1000-grain weight and grain yield were significantly increased by increasing potassium levels. Fertilized wheat plants with $90 \mathrm{~kg} \mathrm{~K} / \mathrm{ha}$ gave significantly higher yield, but on the basis of economic analysis it is recommended that fertilized wheat plants with $60 \mathrm{~kg}$ $\mathrm{K} /$ ha gave better results. Rahimi (2012) showed that effect of potassium on grain yield was highly significant. Increasing the level of potassium to $100 \mathrm{~kg}$ $\mathrm{K}_{2} \mathrm{O} / \mathrm{ha}$, increased grain yield to $4985.3 \mathrm{~kg} / \mathrm{ha}$. Tababtabaei and Ranjbar (2012) indicated that the highest grain and straw yields were obtained by application of $90 \mathrm{~kg} \mathrm{~K} \mathrm{~K}_{2} \mathrm{O} / \mathrm{ha}$. Using different amount of potassium had no any effect on grain protein.

Therefore, this investigation was established to determine the effect of nitrogen and compost combination treatments and potassium fertilizer levels as well as their interactions on growth, yield and its components as well as grain quality of some wheat cultivars under the environmental conditions of El-Serw district, Damietta Governorate.

\section{MATERIALS AND METHODS}

Two field experiments were conducted at the Experimental Research Station in El-Serw, Agricultural Research Center (ARC) during the two successive winter seasons of 2010/2011 and 2011/2012. The objective of these experiments was to improve some wheat cultivars productivity under organic and minerals fertilization.

The experiments were carried out in a strip-split plot design with three replicates. The vertical plots were assigned to three wheat cultivars (Sakha 93, Gemmiza 9 and Gemmiza 10). 
Salama, A. M. A. et al.

The Horizontal plots were devoted to five nitrogen and compost combination treatments as follows:

1. $100 \%$ mineral nitrogen $(90 \mathrm{~kg} / \mathrm{fed})$.

2. $75 \%$ mineral nitrogen $(67.5 \mathrm{~kg} / \mathrm{fed})+25 \%$ organic nitrogen "compost" $(22.5 \mathrm{~kg} / \mathrm{fed})$.

3. $50 \%$ mineral nitrogen $(45.0 \mathrm{~kg} / \mathrm{fed})+50 \%$ organic nitrogen "compost" $(45.0 \mathrm{~kg} / \mathrm{fed})$.

4. $25 \%$ mineral nitrogen $(22.5 \mathrm{~kg} / \mathrm{fed})+75 \%$ organic nitrogen "compost" $(67.5 \mathrm{~kg} / \mathrm{fed})$

5. $100 \%$ organic nitrogen "compost" $(90 \mathrm{~kg} / \mathrm{fed})$.

The compost was obtained from El-Asria Company for Solid Waste Recycling and added after soil preparation to the experimental units at the previously mentioned rates on soil surface and then turned over via hack. Analysis of used compost was shown in Table 1. The nitrogen fertilizer in the form of ammonium nitrate $(33.5 \% \mathrm{~N})$ was applied at the aforementioned rates in two equal doses prior the first ( 25 days from sowing) and the second (46 days from sowing) irrigations.

While, the sub - plots were allocated to two potassium fertilizer levels ( 0 and $48 \mathrm{~kg} \mathrm{~K}_{2} \mathrm{O} / \mathrm{fed}$ ).

The potassium fertilizer in the form of potassium sulphate $\left(48 \% \mathrm{~K}_{2} \mathrm{O}\right)$ at formerly mentioned rates was applied broadcasting in one dose before the first irrigation.

Each experimental unit was $3 \times 3.5 \mathrm{~m}$ occupying an area of $10.5 \mathrm{~m}^{2}$ (i.e. 1/400 feddan). The preceding summer crop was rice (Oryza sativa, L.) in both seasons. fertility.

The experiments were carried out in a clay loam soil with medium

Table 1: Chemical analysis of used compost.

\begin{tabular}{|l|c|}
\hline \multicolumn{1}{|c|}{ Properties } & Value \\
\hline Weight & $680 \mathrm{~kg} / \mathrm{m}^{3}$ \\
\hline Moisture & $27.5 \%$ \\
\hline Organic matter & $33.1 \%$ \\
\hline Total N & $1.4 \%$ \\
\hline Total P & $0.7 \%$ \\
\hline Total K & $1.0 \%$ \\
\hline Organic carbon & $19.6 \%$ \\
\hline $\mathrm{C} / \mathrm{N} \mathrm{ratio}$ & $16: 1$ \\
\hline $\mathrm{NaCl}$ & $1.5 \%$ \\
\hline $\mathrm{Fe}$ & $1650 \mathrm{ppm}$ \\
\hline $\mathrm{Mn}$ & $35 \mathrm{ppm}$ \\
\hline $\mathrm{Zn}$ & $180 \mathrm{ppm}$ \\
\hline $\mathrm{Cu}$ & $105 \mathrm{ppm}$ \\
\hline $\mathrm{pH}$ & 7.7 \\
\hline E.C. & $3.1 \mathrm{mho} / \mathrm{cm}$ \\
\hline
\end{tabular}


Soil samples were taken at random from the experimental field area at a depth of 0 and $30 \mathrm{~cm}$ from soil surface before soil preparation to measure the physical and chemical soil properties as shown in Table 2. Calcium super phosphate $\left(15.5 \% \mathrm{P}_{2} \mathrm{O}_{5}\right)$ was applied during soil preparation at the rate of $150 \mathrm{~kg} / \mathrm{fed}$.

Sowing took place on November $15^{\text {th }}$ and $18^{\text {th }}$ in the first and second seasons, respectively. Wheat grains at the rate of $75 \mathrm{~kg} / \mathrm{fed}$ were sown by using broadcasting Afir method. The first irrigation was applied at 25 days after sowing and then plants were irrigated every 21 days till the dough stage. The common agricultural practices for growing wheat according to the recommendations of Ministry of Agriculture were followed, except the factors under study.

\section{STUDIED CHARACTERS:}

\section{A- Growth characters:}

1 - Number of days to heading.

After 120 days from sowing, one square meter was randomly chosen from each sub - plot to estimate the following characters:

Table 2: Physical and chemical soil characteristics at the experimental sites during the two seasons.

\begin{tabular}{|c|c|c|c|}
\hline Soil analysis & & $2010 / 2011$ & 2011/2012 \\
\hline A: Mechanical anal & ysis & & \\
\hline Clay (\%) & & 65.95 & 66.10 \\
\hline Silt (\%) & & 22.26 & 21.67 \\
\hline Fine sand (\%) & & 10.35 & 11.23 \\
\hline Coarse sand (\%) & & 1.44 & 1.09 \\
\hline Texture class & & Clayey & Clayey \\
\hline B: Chemical analys & & & \\
\hline $\mathrm{pH}$ & & 8.00 & 8.01 \\
\hline E.C. $\left(\mathrm{mho} / \mathrm{cm}\right.$ at $25^{\circ}$ & & 2.41 & 2.32 \\
\hline Organic matter (\%) & & 0.86 & 0.75 \\
\hline C.E.C. $(\mathrm{meq} / 100 \mathrm{~g} \mathrm{~s}$ & oil) & 42.30 & 44.10 \\
\hline $\mathrm{CaCO}_{3}(\%)$ & & 1.34 & 1.41 \\
\hline Total nitrogen (\%) & & 0.033 & 0.031 \\
\hline Available P (ppm) & & 7.94 & 8.01 \\
\hline Available K (ppm) & & 479.0 & 483.0 \\
\hline & $\mathrm{Ca}^{++}$ & 3.11 & 2.95 \\
\hline Cations (mea /100 & $\mathrm{Mg}^{++}$ & 2.69 & 2.81 \\
\hline g soil) & $\mathrm{Na}^{+}$ & 11.40 & 11.21 \\
\hline & $\mathrm{K}^{+}$ & 0.28 & 0.27 \\
\hline Anions /mog/100 al & $\mathrm{HCO}_{3}$ & 1.70 & 1.59 \\
\hline Anıons (meq./100 g & $\mathrm{Cl}^{-}$ & 12.21 & 12.02 \\
\hline & $\mathrm{SO}_{4}$ & 3.68 & 3.63 \\
\hline
\end{tabular}

2- Flag leaf area $\left(\mathrm{cm}^{2}\right)$. It was calculated by the following formula: $\mathrm{a}=\mathrm{L} \times \mathrm{W} \times 0.75$ (Gardner et al., 1985).

Where; $a=$ Flag leaf area, $L=$ Length of flag leaf and $W=$ Maximum width of flag leaf. 
Salama, A. M. A. et al.

3- Plant height (cm).

B- Yield and its components:

At harvesting, one square meter was randomly selected from each sub - plot to estimate the following characters:

4- Number of spikes $/ \mathrm{m}^{2}$.

6- Number of spikelets/spike.

8- Grains weight/spike (g).

10- Grain yield (ardab/fed).

C- Grain quality characters:

12- Crude protein percentage in grains. Total nitrogen was estimated by the improved Kjeldahl - method according to A.O.A.C. method (1990), modified by distilling the ammonia into saturated boric solution and titration in standard acid. Crude protein percentage was calculated by multiplying the total nitrogen values in wheat flour by 5.75 .

13- Potassium (\%) was determined using a flame photometer according to Black (1965).

All data were statistically analyzed according to the technique of analysis of variance (ANOVA) for the strip split - plot design as published by Gomez and Gomez (1984) by means of "MSTAT-C" Computer software package. Least significant of difference (LSD) method was used to test the differences between treatment means at $5 \%$ level of probability as described by Snedecor and Cochran (1980).

\section{RESULTS AND DISCUSSION}

\section{Cultivars performance:}

Significant differences among the three studied wheat cultivars i.e. Sakha 93, Gemmiza 9 and Gemmiza 10 were detected in flag leaf area (in the first season), plant height, number of spikes $/ \mathrm{m}^{2}$, spike length, number of spikelets/spike, number of grains/spike, grains weight/spike, 1000-grain weight, grain and straw yields/fed, protein and potassium percentages in grains during the two growing seasons as shown from data in Tables 3 and 4 . Gemmiza 10 cultivar surpassed other studied cultivars (Gemmiza 9 and Sakha 93) in number of days to heading, flag leaf area, plant height, number of spikes $/ \mathrm{m}^{2}$, number of spikelets/spike, number of grains/spike, grains weight/spike, grain and straw yields/fed, potassium content in grains, which recorded the highest values of these characters in the two growing seasons. However, Gemmiza 9 cultivar registered the longest spikes and the highest values of protein percentage in grains in both seasons. Whereas, Sakha 93 cultivar recorded the highest values of 1000 - grain weight at the same time the lowest values of other studied characters in both seasons of this study. These findings might be attributed to the differences in their genetical constitution and genetic factors makeup. These results are in agreement with those detected by El-Metwally et al. (2012), Harb et al. (2012) and Seleem and Abd El-Dayem (2013).

2. Effect of nitrogen and compost combination treatments:

From obtained results in Tables 3 and 4, combined application of mineral nitrogen fertilizer and organic manure as compost treatments showed 
significant effect on all studied characters in both growing seasons. Application of $100 \%$ mineral nitrogen fertilizer alone significantly increased growth characters, yield and yield components as well as crude protein percentages in grains in both seasons. Application of $75 \%$ mineral nitrogen $(67.5 \mathrm{~kg} / \mathrm{fed})+25 \%$ organic nitrogen "compost" $(22.5 \mathrm{~kg} / \mathrm{fed})$ came in the second rank after application of $100 \%$ mineral nitrogen alone without significant differences between them in some studied characters, except potassium percentages in grains in both seasons. This treatment may be recommended when taking into consideration the economic costs and also environmental pollution with nitrite and nitrate. Application of $50 \%$ mineral nitrogen $(45.0 \mathrm{~kg} / \mathrm{fed})+50 \%$ organic nitrogen "compost" $(45.0 \mathrm{~kg} / \mathrm{fed})$ came in the third rank followed by application of $25 \%$ mineral nitrogen $(22.5 \mathrm{~kg} / \mathrm{fed})$ + $75 \%$ organic nitrogen "compost" $(67.5 \mathrm{~kg} / \mathrm{fed})$ with respect to all studied characters, except for potassium percentages in grains in both seasons. On the other hand, application of $100 \%$ organic manure as compost alone gave the lowest values of all studied characters, except for potassium percentages in grains which was the highest with the application of $100 \%$ organic manure followed by $75 \%, 50 \%$ and $25 \%$ in a descending order. These results might be due to the low soil content of available nitrogen, phosphorus and potassium (Table 2), since nitrogen is considered as one of the major elements for plant nutrition and it increases the vegetative growth of plants through encouraging plants to uptake other elements and consequently improving photosynthesis and all yield components. It was worthy to mentioned that the decrease in grain yield/fed due to the increase in ratio of organic manure in fertilization treatment might be attributed to lower availability and mineralization of nitrogen which released from compost. These results are in compatible with those found by Mahmoud et al. (2006), Abedi et al. (2010), Antoun, Linda et al. (2010) and El-Hamdi et al. (2012).

\section{Effect of potassium fertilizer levels:}

The effect of potassium fertilizer levels, it was significant for all studied characters in the two seasons, except number of grains/spike it was not significant and grains weight/spike it was significant in the second season only (Tables 3 and 4). All studied characters of wheat plants gradually increased as a result of increasing potassium fertilizer levels from 0 to $48 \mathrm{~kg}$ $\mathrm{K}_{2} \mathrm{O} / \mathrm{fed}$ in both seasons. Generally, maximum means of all studied characters resulted from fertilizing wheat plants with $48 \mathrm{~kg} \mathrm{~K}_{2} \mathrm{O} / \mathrm{fed}$ in both seasons. On the contrary, the lowest values of these characters were obtained from plots did not receive potassium fertilizer (control treatment). The increase in all studied characters as a result to increasing potassium fertilizer levels can be easily ascribed to the potential benefits of potassium for wheat which include promoting early plant maturity, resistance to diseases and other pests increasing, stalk strength, tillering, growth, and finally grain and straw yields (Slaton et al., 2007). These results are in agreement with those reported by many workers including Tahir et al. (2008), Rahimi (2012) and Tababtabaei and Ranjbar (2012). 
Salama, A. M. A. et al.

t1 
J. Plant Production, Mansoura Univ., Vol. 5 (1), January, 2014

t2 
Salama, A. M. A. et al.

\section{Effect of interactions:}

Regarding the effect of interactions, there are many significant effects of the interactions on the studied characters. We present only the effect of significant interactions on grain yield (Tables 5-8).

Table 5: Grain yield (ardab/fed) as affected by the interaction between cultivars and nitrogen and compost combination treatments during 2010/2011 and 2011/2012 seasons.

\begin{tabular}{|c|c|c|c|c|c|}
\hline \multirow[b]{2}{*}{ Cultivars } & \multicolumn{5}{|c|}{ Nitrogen and compost combination treatments } \\
\hline & $100 \% \mathrm{~N}$ & $\begin{array}{c}75 \% \text { N + } \\
25 \% \text { C }\end{array}$ & $\begin{array}{c}50 \% \mathrm{~N}+ \\
50 \% \mathrm{C}\end{array}$ & $\begin{array}{c}25 \% \text { N + } \\
75 \% \text { C }\end{array}$ & $100 \% C$ \\
\hline \multicolumn{6}{|c|}{ 2010/2011 season } \\
\hline Sakha 93 & 15.52 & 15.13 & 14.40 & 12.66 & 11.45 \\
\hline Gemmiza 9 & 17.11 & 16.26 & 15.67 & 12.74 & 11.54 \\
\hline Gemmiza 10 & 17.53 & 16.95 & 15.57 & 14.06 & 11.64 \\
\hline F. test & \multicolumn{5}{|c|}{ * } \\
\hline LSD at $5 \%$ & \multicolumn{5}{|c|}{0.37} \\
\hline \multicolumn{6}{|c|}{ 2011/2012 season } \\
\hline Sakha 93 & 16.65 & 16.41 & 15.65 & 12.83 & 11.63 \\
\hline Gemmiza 9 & 17.25 & 16.54 & 16.01 & 12.92 & 11.75 \\
\hline Gemmiza 10 & 17.67 & 17.06 & 15.92 & 13.61 & 11.80 \\
\hline F. test & \multicolumn{5}{|c|}{-} \\
\hline LSD at $5 \%$ & & & 0.44 & & \\
\hline
\end{tabular}

The interaction between cultivars and nitrogen combination treatments had a significant effect on grain yield/fed in both seasons. Data presented in Table 5 show that, the highest values of grain yield/fed (17.53 and $17.67 \mathrm{ardab} / \mathrm{fed}$ ) were obtained when Gemmiza 10 cultivar revived $90 \mathrm{~kg}$ $\mathrm{N} / \mathrm{fed}$ in the first and second seasons, respectively. Gemmiza 9 cultivar with $90 \mathrm{~kg} \mathrm{~N} / \mathrm{fed}$ ranked after the aforementioned interaction treatment without significant differences between them in the second season.

Grain yield/fed was significantly affected by the interaction between cultivars and potassium fertilizer levels in both seasons. From data listed in Table 6 the highest values of grain yield/fed (15.12 and 15.33 ardab/fed) were obtained as a result of fertilizing Gemmiza 10 cultivar with the highest level of potassium fertilizer ( $48 \mathrm{~kg} \mathrm{~K} \mathrm{O} / \mathrm{fed}$ ) in the first and second seasons, respectively. This treatment followed by fertilizing Gemmiza 9 cultivar with 48 $\mathrm{kg} \mathrm{K}_{2} \mathrm{O} / \mathrm{fed}$ without significant differences in the second season. 
Table 6: Grain yield (ardab/fed) as affected by the interaction between cultivars and potassium fertilizer levels during 2010/2011 and 2011/2012 seasons.

\begin{tabular}{|l|c|c|}
\hline \multirow{2}{*}{ Cultivars } & \multicolumn{2}{|c|}{ Potassium fertilizer levels } \\
\cline { 2 - 3 } & $0 \mathrm{~kg} \mathrm{~K}$ O/fed & $48 \mathrm{~kg} \mathrm{~K} \mathrm{O}_{2} \mathrm{fed}$ \\
\hline $\mathbf{2 0 1 0 / 2 0 1 1}$ season & 13.73 & 13.96 \\
\hline Sakha 93 & 14.73 & 15.01 \\
\hline Gemmiza 9 & 14.74 & 15.12 \\
\hline Gemmiza 10 & \multicolumn{2}{|c|}{0.09} \\
\hline F. test & 14.42 & 14.84 \\
\hline LSD at 5\% & 14.80 & 15.25 \\
\hline 2011/2012 season & 14.83 & 15.33 \\
\hline Sakha 93 & * \\
\hline Gemmiza 9 & \multicolumn{2}{|c|}{0.11} \\
\hline Gemmiza 10 & F. test & \\
\hline LSD at 5\% &
\end{tabular}

Table 7: Grain yield (ardab/fed) as affected by the interaction between nitrogen and compost combination treatments and potassium levels during 2010/2011 and 2011/2012 seasons.

\begin{tabular}{|c|c|c|}
\hline \multirow{2}{*}{$\begin{array}{l}\text { Nitrogen and compost } \\
\text { combination treatments }\end{array}$} & \multicolumn{2}{|c|}{ Potassium fertilizer levels } \\
\hline & $0 \mathrm{~kg} \mathrm{~K}_{2} \mathrm{O} / \mathrm{fed}$ & $48 \mathrm{~kg} \mathrm{~K}_{2} \mathrm{O} / \mathrm{fed}$ \\
\hline \multicolumn{3}{|l|}{\begin{tabular}{|l|}
$2010 / 2011$ season \\
\end{tabular}} \\
\hline $100 \% \mathrm{~N}$ & 16.55 & 16.88 \\
\hline $75 \% N+25 \% c$ & 16.01 & 16.22 \\
\hline $50 \% N+50 \% C$ & 15.08 & 15.35 \\
\hline $25 \% \mathrm{~N}+75 \% \mathrm{C}$ & 13.00 & 13.31 \\
\hline $100 \% \mathrm{C}$ & 11.37 & 11.72 \\
\hline F. test & \multicolumn{2}{|c|}{012} \\
\hline LSD at $5 \%$ & & \\
\hline \multicolumn{3}{|l|}{ 2011/2012 season } \\
\hline $100 \% \mathrm{~N}$ & 17.03 & 17.35 \\
\hline $75 \% N+25 \% C$ & 16.48 & 16.85 \\
\hline $50 \% N+50 \% C$ & 15.60 & 16.12 \\
\hline $25 \% \mathrm{~N}+75 \% \mathrm{C}$ & 12.81 & 13.43 \\
\hline $100 \% \mathrm{C}$ & 11.48 & 11.97 \\
\hline F. test & \multicolumn{2}{|c|}{ * } \\
\hline LSD at $5 \%$ & \multicolumn{2}{|c|}{0.15} \\
\hline
\end{tabular}

The interaction between nitrogen and compost combination treatments and potassium fertilizer levels significantly affected grain yield per feddan in both seasons. Fertilizing wheat plants with $90 \mathrm{~kg} \mathrm{~N}+48 \mathrm{~kg} \mathrm{~K} \mathrm{~K}_{2} \mathrm{O} / \mathrm{fed}$ produced the highest values of grain yield (16.88 and $17.35 \mathrm{ardab} / \mathrm{fed}$ ) in the first and second seasons, respectively (Table 7 ). This treatment followed by 
Salama, A. M. A. et al.

fertilizing wheat plants with mineral nitrogen $(67.5 \mathrm{~kg} \mathrm{~N} / \mathrm{fed})+$ compost $(22.5$ $\mathrm{kg} \mathrm{N} / \mathrm{fed})+48 \mathrm{~kg} \mathrm{~K} \mathrm{O}_{2} / \mathrm{fed}$ in both seasons.

The interaction among cultivars, nitrogen and compost combination treatments and potassium fertilizer levels excreted significant effect on grain yield/fed in both seasons. The highest values of grain yield/fed (17.64 and $17.88 \mathrm{ardab} / \mathrm{fed}$ ) were obtained from fertilizing Gemmiza 10 cultivar plants with $90 \mathrm{~kg} \mathrm{~N}+48 \mathrm{~kg} \mathrm{~K} \mathrm{~K}_{2} \mathrm{O} / \mathrm{fed}$ in the first and second seasons, respectively (Table 8). This interaction treatment followed by fertilizing Gemmiza 9 cultivar plants with $90 \mathrm{~kg} \mathrm{~N}+48 \mathrm{~kg} \mathrm{~K} \mathrm{O}_{2} \mathrm{fed}$ in both seasons.

Table 8: Grain yield (ardab/fed) as affected by the interaction among cultivars, nitrogen and compost combination treatments and potassium levels during 2010/2011 and 2011/2012 seasons.

\begin{tabular}{|c|c|c|c|}
\hline \multirow{2}{*}{ Cultivars } & \multirow{2}{*}{$\begin{array}{l}\text { Nitrogen and compost } \\
\text { combination treatments }\end{array}$} & \multicolumn{2}{|c|}{ Potassium fertilizer levels } \\
\hline & & $0 \mathrm{~kg} \mathrm{~K} \mathrm{~K}_{2} \mathrm{O} / \mathrm{fed}$ & $48 \mathrm{~kg} \mathrm{~K} 2 \mathrm{O} / \mathrm{fed}$ \\
\hline \multicolumn{4}{|c|}{ 2010/2011 season } \\
\hline \multirow{5}{*}{ Sakha 93} & $100 \% \mathrm{~N}$ & 15.31 & 15.73 \\
\hline & $75 \% N+25 \% C$ & 15.11 & 15.15 \\
\hline & $50 \% N+50 \% C$ & 14.28 & 14.51 \\
\hline & $25 \% N+75 \% C$ & 12.60 & 12.88 \\
\hline & $100 \% \mathrm{C}$ & 11.30 & 11.60 \\
\hline \multirow{5}{*}{ Gemmiza 9} & $100 \% \mathrm{~N}$ & 16.93 & 17.28 \\
\hline & $75 \% N+25 \% C$ & 16.06 & 16.46 \\
\hline & $50 \% N+50 \% C$ & 15.51 & 15.84 \\
\hline & $25 \% N+75 \% C$ & 13.88 & 14.24 \\
\hline & $100 \% \mathrm{C}$ & 11.32 & 11.77 \\
\hline \multirow{5}{*}{ Gemmiza 10} & $100 \% \mathrm{~N}$ & 17.42 & 17.64 \\
\hline & $75 \% N+25 \% C$ & 16.82 & 17.08 \\
\hline & $50 \% N+50 \% C$ & 15.44 & 15.71 \\
\hline & $25 \% N+75 \% C$ & 12.51 & 12.82 \\
\hline & $100 \% \mathrm{C}$ & 11.48 & 11.80 \\
\hline \multicolumn{2}{|l|}{ F. test } & \multicolumn{2}{|l|}{ 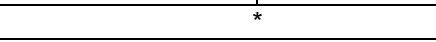 } \\
\hline \multicolumn{2}{|l|}{ LSD at $5 \%$} & \multicolumn{2}{|c|}{0.19} \\
\hline \multicolumn{4}{|c|}{ 2011/2012 season } \\
\hline \multirow{5}{*}{ Sakha 93} & $100 \% \mathrm{~N}$ & 16.51 & 16.80 \\
\hline & $75 \% N+25 \% C$ & 16.22 & 16.60 \\
\hline & $50 \% N+50 \% C$ & 15.40 & 15.91 \\
\hline & $25 \% N+75 \% C$ & 12.57 & 13.08 \\
\hline & $100 \% \mathrm{C}$ & 11.42 & 11.84 \\
\hline \multirow{5}{*}{ Gemmiza 9} & $100 \% \mathrm{~N}$ & 17.13 & 17.37 \\
\hline & $75 \% N+25 \% C$ & 16.40 & 16.68 \\
\hline & $50 \% N+50 \% C$ & 15.80 & 16.22 \\
\hline & $25 \% N+75 \% C$ & 13.22 & 14.00 \\
\hline & $100 \% \mathrm{C}$ & 11.44 & 12.00 \\
\hline \multirow{5}{*}{ Gemmiza 10} & $100 \% \mathrm{~N}$ & 17.46 & 17.88 \\
\hline & $75 \% N+25 \% C$ & 16.84 & 17.28 \\
\hline & $50 \% N+50 \% C$ & 15.60 & 16.24 \\
\hline & $25 \% N+75 \% C$ & 12.65 & 13.20 \\
\hline & $100 \% \mathrm{C}$ & 11.60 & 12.06 \\
\hline \multicolumn{2}{|l|}{ F. test } & \multicolumn{2}{|r|}{ 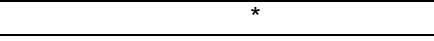 } \\
\hline \multicolumn{2}{|l|}{ LSD at $5 \%$} & \multicolumn{2}{|c|}{0.26} \\
\hline
\end{tabular}


It could be recommended that fertilizing Gemmiza 10 cultivar plants with mineral nitrogen $(67.5 \mathrm{~kg} \mathrm{~N} / \mathrm{fed})+$ compost $(22.5 \mathrm{~kg} \mathrm{~N} / \mathrm{fed})+48 \mathrm{~kg}$ $\mathrm{K}_{2} \mathrm{O} / \mathrm{fed}$ to enhance wheat productivity and also to reduce sources of environmental pollution and maintain human health.

\section{REFERENCES}

A.O.A.C. (1990). Official Methods of Analysis. $15^{\text {th }}$ Ed. Association of Official Analytical Chemists, Inc., Virginia, USA, pp: 770-771.

Abedi, T. ; A. Alemzadeh and S.A. Kazemeini (2010). Effect of organic and inorganic fertilizers on grain yield and protein banding pattern of wheat. Australian J. of Crop Sci., 4(6): 384-389.

Antoun, Linda W. ; Sahar M. Zakaria and Hanaa H. Rafla (2010). Influence of compost, N-mineral and humic acid on yield and chemical composition of wheat plants. J. Soil Sci. and Agric. Engi., Mansoura Univ., 1(11): 1131- 1143.

Atia, R.H. and Kh.E. Ragab (2013). Response of some wheat varieties to nitrogen fertilization. J. Soil Sci. and Agric. Eng., Mansoura Univ., 4(3): $309-319$.

Black, C.A. (1965). Methods of soil analysis. Part I- Physical and mineralogical properties. A.S.A. Madison, Wisc., USA.

El-Hamdi, Kh. H. ; A. R. Ahmed and N. E. S. El-Azzony (2012). Effect of compost, nitrogen and micronutrient compounds on nitrogen uptake, yield and yield components of wheat. J. Soil Sci. and Agric. Eng., Mansoura Univ., 3(11): 1043 - 1056.

El-Metwally, A.El-M. ; N.A. Khalil ; M.M. El-Fouly and M.F. El-Dahshouri (2012). Growth, nutrients uptake and grain yield of some wheat cultivars as affected by zinc application under sandy soil conditions. J. Plant Production, Mansoura Univ., 3(5): 773 - 783.

Gardner, F.P. ; R.B. Pearce and R.L. Michell (1985). Physiology of crop plant. lowa State Univ. Press Ames. lowa. USA pp. 58-75 (C.F. Computer Search).

Gomez, K.N. and A.A. Gomez (1984). Statistical procedures for agricultural research. John Wiley and Sons, New York, 2nd Ed., 68 P.

Harb, O.M.S. ; G.H. Abd El-Hay ; M.A. Hager ; M.K. Hassanien and M.M. Abou El-Enin (2012) Effect of water irrigation quantity and compost rates on some wheat varieties under sandy soil conditions of West Delta region conditions. J. Plant Production, Mansoura Univ., 3(5): 847 $-855$.

Mahmoud, M. M. ; Gehan H. Youssef and Wafaa M. A. Saddik (2006). Partial replacement of $\mathrm{N}$-mineral requirements by $\mathrm{N}$-organic source as related to both sesame-wheat yields and their components. Egypt. J. Appl. Sci., 21(6B) 12 - 21.

Odlare, M. ; M. Pell and K. Svensson (2008). Changes in soil chemical and microbiological properties during 4 years of application of various organic residues. Waste Manag., 28: 1246-1253. 
Rahimi, A. (2012). Effect of potassium and nitrogen on yield and yield components of dry land wheat in Boyerahmad Region of Iran. Annals of Biol. Res., 3 (7): 3274-3277.

Seleem, S.A. and S.M. Abd El-Dayem (2013). Response of some wheat cultivars to nitrogen fertilizer levels. J. Plant Production, Mansoura Univ., 4(5): $721-731$.

Slaton, N.A. ; R.E. DeLong ; M. Mozaffari ; S. Clark ; C. Allen and R. Thompson (2007). Wheat grain yield response to phosphorus and potassium fertilizer rate. AAES Research Series, 558: 69-71.

Snedecor, G.W. and W.G. Cochran (1980). "Statistical Methods" 7th Ed. The lowa State Univ. Press, lowa, USA.

Tababtabaei, S.A. and G.H. Ranjbar (2012). Effect of different levels of nitrogen and potassium on grain yield and protein of wheat. Intl. Res. J. Appl. Basic. Sci., 3(2): 390-393.

Tahir, M. ; A. Tanveer ; A. Ali ; M. Ashraf and A. Wasaya (2008). Growth and yield response of two wheat (Triticum aestivum $L$.) varieties to different potassium levels. Pakistan J. Life Soc. Sci., 6(2): 92-95.

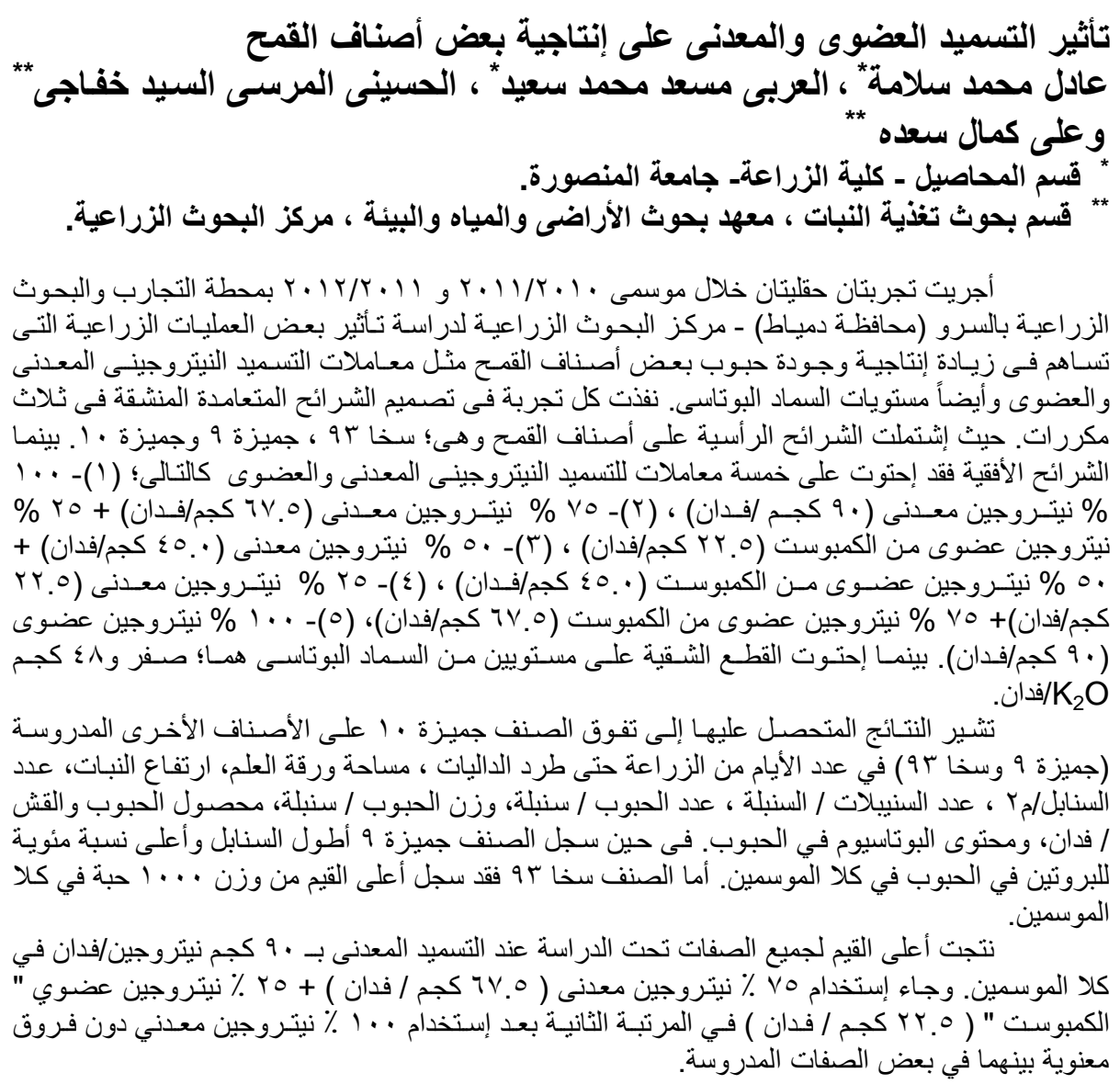




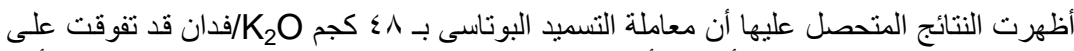

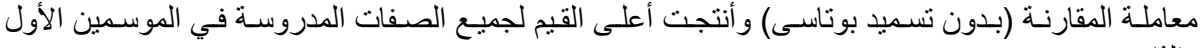

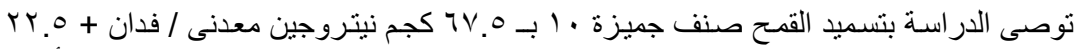

و الثاني.

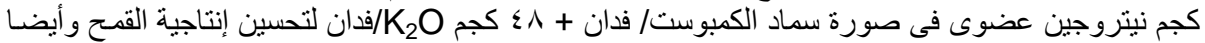

للحد من مصادر التلوث البيئي و الحفاظ على صحة الإنسان تحت ظروف محان محافظة دمياط.

قام بتحكيم البحث

كلية الزراعة - جامعة المنصورة

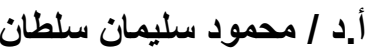

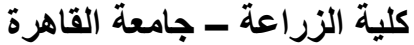

أ.د / السيد عبد العزيز محمود سليمان سطان 

Table 3: Number of days to heading, flag leaf area, plant height, number of spikes $/ \mathrm{m}^{2}$, spike length, number of spikelets/spike and number of grains/spike as affected by cultivars, nitrogen and compost combination treatments and potassium fertilizer levels as well as their interactions during 2010/2011 and 2011/2012 seasons.

\begin{tabular}{|c|c|c|c|c|c|c|c|c|c|c|c|c|c|c|}
\hline \multirow{2}{*}{$\begin{array}{l}\text { Characters } \\
\text { Seasons } \\
\text { Treatments }\end{array}$} & \multicolumn{2}{|c|}{$\begin{array}{c}\text { Number of days } \\
\text { to heading }\end{array}$} & \multicolumn{2}{|c|}{$\begin{array}{c}\text { Flag leaf area } \\
\left(\mathrm{cm}^{2}\right)\end{array}$} & \multicolumn{2}{|c|}{ Plant height $(\mathrm{cm})$} & \multicolumn{2}{|c|}{$\begin{array}{l}\text { Number of } \\
\text { spikes } / \mathrm{m}^{2}\end{array}$} & \multicolumn{2}{|c|}{$\begin{array}{l}\text { Spike length } \\
\text { (cm) }\end{array}$} & \multicolumn{2}{|c|}{$\begin{array}{c}\text { Number of } \\
\text { spikelets/spike }\end{array}$} & \multicolumn{2}{|c|}{$\begin{array}{c}\text { Number of } \\
\text { grains/spike }\end{array}$} \\
\hline & $\begin{array}{l}2010 \\
/ 2011 \\
\end{array}$ & $\begin{array}{l}2011 \\
/ 2012 \\
\end{array}$ & $\begin{array}{l}2010 \\
/ 2011 \\
\end{array}$ & $\begin{array}{l}2011 \\
/ 2012 \\
\end{array}$ & $\begin{array}{l}2010 \\
2011 \\
\end{array}$ & $\begin{array}{l}2011 \\
/ 2012 \\
\end{array}$ & $\begin{array}{l}2010 \\
/ 2011 \\
\end{array}$ & $\begin{array}{l}2011 \\
/ 2012 \\
\end{array}$ & $\begin{array}{l}2010 \\
/ 2011 \\
\end{array}$ & $\begin{array}{l}2011 \\
/ 2012 \\
\end{array}$ & $\begin{array}{l}2010 \\
/ 2011 \\
\end{array}$ & $\begin{array}{l}2011 \\
/ 2012 \\
\end{array}$ & $\begin{array}{l}2010 \\
/ 2011 \\
\end{array}$ & $\begin{array}{r}2011 \\
/ 2012 \\
\end{array}$ \\
\hline \multicolumn{15}{|l|}{ A- Cultivars: } \\
\hline Sakha 93 & 90.63 & 90.83 & 37.38 & 36.39 & 87.06 & 88.23 & 250.4 & 249.8 & 9.22 & 9.37 & 17.93 & 17.10 & 50.26 & 49.70 \\
\hline Gemmiza 9 & 90.73 & 91.30 & 38.87 & 36.62 & 95.73 & 92.06 & 255.7 & 256.5 & 10.22 & 10.06 & 18.46 & 18.20 & 50.66 & 49.80 \\
\hline Gemmiza 10 & 91.06 & 91.40 & 39.60 & 37.03 & 103.83 & 95.83 & 256.1 & 259.6 & 9.52 & 9.40 & 19.36 & 18.80 & 52.50 & 51.93 \\
\hline F. test & NS & NS & * & NS & * & 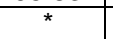 & * & * & * & 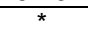 & * & $*$ & 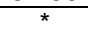 & $*$ \\
\hline LSD at $5 \%$ & 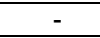 & - & 2.00 & - & 5.94 & 4.63 & 3.7 & 3.5 & 0.19 & 0.16 & 1.12 & 0.97 & 1.16 & 1.44 \\
\hline \multicolumn{15}{|c|}{ B- Nitrogen and compost combination treatments: } \\
\hline $100 \% \mathrm{~N}$ & 94.00 & 94.22 & 43.60 & 43.83 & 102.44 & 103.00 & 289.8 & 289.5 & 11.18 & 11.12 & 22.22 & 21.55 & 59.88 & 58.94 \\
\hline $75 \% N+25 \% C$ & 93.22 & 93.55 & 42.75 & 42.75 & 98.83 & 99.50 & 279.3 & 278.3 & 10.55 & 10.64 & 21.38 & 20.77 & 56.72 & 57.05 \\
\hline $50 \% N+50 \% C$ & 91.33 & 92.55 & 41.95 & 41.47 & 95.33 & 95.72 & 263.1 & 260.1 & 9.80 & 9.78 & 19.55 & 19.50 & 53.83 & 54.27 \\
\hline $25 \% N+75 \% C$ & 88.61 & 88.88 & 35.94 & 31.40 & 94.44 & 85.11 & 227.2 & 234.3 & 8.73 & 8.67 & 16.44 & 15.66 & 45.77 & 43.88 \\
\hline $100 \% \mathrm{C}$ & 86.88 & 86.66 & 28.84 & 23.94 & 86.66 & 76.88 & 211.0 & 214.2 & 7.98 & 7.83 & 13.33 & 12.66 & 39.50 & 38.22 \\
\hline F. test & * & * & * & * & * & * & * & * & * & * & * & * & * & * \\
\hline LSD at $5 \%$ & 0.91 & 0.78 & 2.79 & 1.38 & 4.92 & 3.65 & 4.9 & 4.5 & 0.23 & 0.21 & 1.28 & 0.84 & 2.00 & 1.83 \\
\hline \multicolumn{15}{|c|}{ C- Potassium fertilizer levels: } \\
\hline $0 \mathrm{~kg} \mathrm{~K}_{2} \mathrm{O} / \mathrm{fed}$ & 90.22 & 90.42 & 37.29 & 33.93 & 90.08 & 90.22 & 250.8 & 251.3 & 9.52 & 9.43 & 18.08 & 17.28 & 50.82 & 50.20 \\
\hline $48 \mathrm{~kg} \mathrm{~K}_{2} \mathrm{O} / \mathrm{fed}$ & 91.40 & 91.93 & 39.94 & 39.42 & 101.00 & 93.86 & 257.4 & 259.2 & 9.78 & 9.78 & 19.08 & 18.77 & 51.46 & 50.75 \\
\hline F. test & & & & & & & & & & & & & NS & NS \\
\hline
\end{tabular}


Salama, A. M. A. et al.

\begin{tabular}{|c|c|c|c|c|c|c|c|c|c|c|c|c|c|c|}
\hline \multicolumn{15}{|c|}{$D$ - Interactions: } \\
\hline$A \times B$ & & NS & & NS & NS & & NS & NC & 90 & & NS & NS & NS & \\
\hline$A \times C$ & NS & NS & NS & & NS & 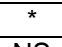 & NS & NS & NS & NS & NS & $\mathrm{NS}$ & & \\
\hline$B \times C$ & NS & NS & & NS & NS & NS & NS & & & & & & NS & NS \\
\hline$A \times B \times C$ & NS & NS & NS & NS & NS & NS & NS & * & NS & NS & NS & * & NS & NS \\
\hline
\end{tabular}


Table 4: Grains weight/spike, 1000 - grain weight, grain and straw yields/fed as well as protein and potassium percentages as affected by cultivars, nitrogen and compost combination treatments and potassium fertilizer levels as well as their interactions during 2010/2011 and 2011/2012 seasons.

\begin{tabular}{|c|c|c|c|c|c|c|c|c|c|c|c|c|}
\hline \multirow{2}{*}{$\begin{array}{l}\text { Characters } \\
\text { Seasons } \\
\text { Treatments }\end{array}$} & \multicolumn{2}{|c|}{$\begin{array}{c}\text { Grains } \\
\text { weight/spike (g) }\end{array}$} & \multicolumn{2}{|c|}{$\begin{array}{c}1000 \text { - grain } \\
\text { weight }(\mathrm{g})\end{array}$} & \multicolumn{2}{|c|}{$\begin{array}{l}\text { Grain yield } \\
\text { (ardab/fed) }\end{array}$} & \multicolumn{2}{|c|}{$\begin{array}{c}\text { Straw yield } \\
(t / f e d)\end{array}$} & \multicolumn{2}{|c|}{$\begin{array}{c}\text { Protein } \\
(\%)\end{array}$} & \multicolumn{2}{|c|}{$\begin{array}{l}\text { Potassium } \\
(\%)\end{array}$} \\
\hline & $\begin{array}{l}2010 \\
/ 2011 \\
\end{array}$ & $\begin{array}{l}2011 \\
/ 2012 \\
\end{array}$ & $\begin{array}{r}2010 \\
/ 2011 \\
\end{array}$ & $\begin{array}{c}2011 \\
/ 2012 \\
\end{array}$ & $\begin{array}{l}2010 \\
/ 2011 \\
\end{array}$ & $\begin{array}{l}2011 \\
/ 2012 \\
\end{array}$ & $\begin{array}{l}2010 \\
/ 2011 \\
\end{array}$ & $\begin{array}{l}2011 \\
/ 2012 \\
\end{array}$ & $\begin{array}{l}2010 \\
/ 2011 \\
\end{array}$ & $\begin{array}{l}2011 \\
/ 2012 \\
\end{array}$ & \begin{tabular}{|l|}
2010 \\
$/ 2011$ \\
\end{tabular} & $\begin{array}{l}2011 \\
/ 2012 \\
\end{array}$ \\
\hline \multicolumn{13}{|l|}{ A-Cultivars: } \\
\hline Sakha 93 & 1.805 & 1.799 & 47.91 & 48.80 & 13.85 & 14.63 & 1.932 & 1.945 & 9.97 & 9.98 & 1.414 & 1.415 \\
\hline Gemmiza 9 & 1.828 & 1.801 & 46.39 & 47.28 & 14.87 & 15.04 & 2.062 & 2.010 & 10.45 & 10.33 & 1.429 & 1.418 \\
\hline Gemmiza 10 & 1.835 & 1.809 & 47.48 & 48.51 & 14.93 & 15.07 & 2.087 & 2.083 & 10.35 & 10.30 & 1.520 & 1.509 \\
\hline F. test & * & * & * & * & * & * & * & * & * & * & * & * \\
\hline LSD at $5 \%$ & 0.010 & 0.007 & 0.37 & 0.44 & 0.13 & 0.20 & 0.051 & 0.092 & 0.28 & 0.21 & 0.052 & 0.050 \\
\hline \multicolumn{13}{|c|}{ B- Nitrogen and compost combination treatments: } \\
\hline $100 \% \mathrm{~N}$ & 1.838 & 1.842 & 49.46 & 49.95 & 16.72 & 17.19 & 2.444 & 2.345 & 11.12 & 11.18 & 1.343 & 1.329 \\
\hline $75 \% N+25 \% C$ & 1.828 & 1.798 & 48.92 & 49.67 & 16.11 & 16.67 & 2.230 & 2.220 & 10.83 & 10.84 & 1.398 & 1.387 \\
\hline $50 \% N+50 \% C$ & 1.823 & 1.793 & 48.09 & 49.20 & 15.21 & 15.86 & 2.076 & 2.146 & 10.57 & 10.48 & 1.438 & 1.439 \\
\hline $25 \% N+75 \% C$ & 1.816 & 1.792 & 46.23 & 47.14 & 13.15 & 13.12 & 1.789 & 1.777 & 9.77 & 9.70 & 1.494 & 1.494 \\
\hline $100 \% \mathrm{C}$ & 1.809 & 1.791 & 43.59 & 45.01 & 11.54 & 11.73 & 1.596 & 1.576 & 9.00 & 8.81 & 1.599 & 1.588 \\
\hline F. test & * & ${ }^{\star}$ & ${ }^{*}$ & ${ }^{*}$ & ${ }^{*}$ & * & * & * & * & * & * & * \\
\hline LSD at $5 \%$ & 0.011 & 0.014 & 0.80 & 0.50 & 0.20 & 0.32 & 0.052 & 0.59 & 0.19 & 0.25 & 0.028 & 0.033 \\
\hline \multicolumn{13}{|c|}{ C- Potassium fertilizer levels: } \\
\hline $0 \mathrm{~kg} \mathrm{~K}_{2} \mathrm{O} / \mathrm{fed}$ & 1.821 & 1.792 & 45.93 & 46.93 & 14.40 & 14.68 & 1.992 & 2.002 & 10.18 & 10.08 & 1.287 & 1.276 \\
\hline $48 \mathrm{~kg} \mathrm{~K}_{2} \mathrm{O} / \mathrm{fed}$ & 1.825 & 1.814 & 48.59 & 49.46 & 14.70 & 15.14 & 2.061 & 2.023 & 10.34 & 10.32 & 1.622 & 1.618 \\
\hline F. test & NS & * & * & * & * & * & * & * & * & * & * & * \\
\hline \multicolumn{13}{|l|}{ D- Interactions: } \\
\hline$A \times B$ & NS & NS & NS & * & * & * & * & * & NS & NS & NS & * \\
\hline$A \times C$ & NS & NS & * & ${ }^{*}$ & ${ }^{*}$ & * & ${ }^{*}$ & * & NS & ${ }^{*}$ & * & * \\
\hline$B \times C$ & NS & NS & * & * & ${ }^{*}$ & * & ${ }^{*}$ & * & ${ }^{*}$ & NS & * & * \\
\hline$A \times B \times C$ & NS & NS & * & * & * & * & NS & NS & NS & NS & NS & NS \\
\hline
\end{tabular}

